\title{
SARS-CoV-2 Pandemic Impact Assessment for Hearing Impaired Patients
}

\author{
Natalia Chilinque Zambão da Silva1 (ㄷ, Manoela Moreira de Oliveira1 (1), \\ Vitória Francisco Pereira1 (1), Ana Carolina Antônio Correia2 ${ }^{2}$ (1) \\ ${ }^{1}$ Universidade Estácio de Sá, Presidente Vargas, Rio de Janeiro, Brazil \\ ${ }^{2}$ Universidade Estácio de Sá, Campus Presidente Vargas, Rio de Janeiro, Brazil \\ Email: nataliazambao@gmail.com, manoela-99@hotmail.com, vitoriafpereira@gmail.com, acarolcorreia@gmail.com
}

How to cite this paper: da Silva, N.C.Z., de Oliveira, M.M., Pereira, V.F. and Correia, A.C.A. (2021) SARS-CoV-2 Pandemic Impact Assessment for Hearing Impaired Patients. Advances in Infectious Diseases, 11, 261-268.

https://doi.org/10.4236/aid.2021.113023

Received: June 2, 2021

Accepted: August 20, 2021

Published: August 23, 2021

Copyright (c) 2021 by author(s) and Scientific Research Publishing Inc. This work is licensed under the Creative Commons Attribution International License (CC BY 4.0).

http://creativecommons.org/licenses/by/4.0/

\begin{abstract}
COVID-19 is a systemic infectious disease caused by the new SARS-CoV-2 coronavirus. The COVID-19 pandemic has caused social, economic, political, and cultural repercussions for humanity. Although Brazilian Sign Language (Libras) has been recognized since 2002 as a legal means of communication and expression, most individuals with hearing impairment in Brazil do not have access to accurate information about SARS-CoV-2 available to them in Libras. Between July 2020 and November 2020, the impact of COVID-19 on deaf and hearing impaired individuals was assessed through a closed questionnaire, using Libras, via a digital platform. Deaf and hearing impaired individuals over 18 years of age and living in the Metropolitan Region II of Rio de Janeiro were eligible to participate. Frequencies were calculated for categorical variables. From the total questionnaires submitted, 55.5\% of respondents claim to have "a lot" of knowledge regarding COVID-19, and $44.4 \%$ of those individuals indicated they gained this knowledge through social media. Additionally, the main difficulties encountered by the deaf and hearing impaired population during the pandemic were: communicating with others wearing masks, and poor access to medical care. Thus, for full physical, mental, and social well-being, the state must invest in the inclusion of this population through public health measures.
\end{abstract}

\section{Keywords}

COVID-19, Deafness, Pandemic

\section{Introduction}

According to Decree No 5.626 of December 22, 2005 and determined by the Civil House of the Presidency of the Republic, "a deaf person is considered to be one 
who, because of hearing loss, represents and interacts with the world through visual experiences, manifesting their culture, mainly through the use of the Brazilian Sign Language (Libras)"1. There are approximately 9 million people with hearing problems in Brazil. This group, however, is not homogeneous. They are children, young people, adults, and the elderly who all have hearing impairments to various degrees. Impairments have a direct impact on the form of communication these citizens use in their lives [1].

The impact of these impairments worsened during the SARS-CoV-2 pandemic. COVID-19 is a highly transmissible disease, and one of the non-pharmacological preventive measures is the use of facial masks [2]. As such, masks became a major obstacle for these individuals who depend on lip-reading as well as the ability to see facial expressions for proper communication. In addition, access to information becomes difficult as up-to-the-minute facts regarding COVID-19 are not transmitted in an accessible way to the deaf and hearing impaired population using Libras [3].

Therefore, the objective of this study was to analyse the impact of the SARS-CoV-2 pandemic on the deaf and hearing impaired population in the Metropolitan Region II of Rio de Janeiro, as well as to evaluate the knowledge of this population group regarding COVID-19.

\section{Methods}

Qualitative research, of scientific initiation, in which the data was collected through a questionnaire prepared by students using Libras, and made available on the digital platform SurveyMonkey (Table 1 and Figure 1). The questionnaire was available from July 2020 to November 2020. Prior to the release of the questionnaire, it was validated by three (3) Libras teachers. The level of knowledge of the participants was evaluated according to definitions and publications from the Brazilian Ministry of Health. The access link to the response form was sent via email and through WhatsApp to hearing impaired associations in each municipality. Deaf and hearing impaired individuals over 18 years of age and living in the Metropolitan Region II of Rio de Janeiro (Niterói, Itaboraí, Maricá, Rio Bonito, São Gonçalo, Silva Jardim, and Tanguá) were eligible to participate. The study population is a convenience sample, without sample calculation, based on the prevalence of hearing impairment contained in the IBGE (Brazilian Institute of Geography and Statistics) database. Questionnaires without sufficient data for analysis were excluded. There was no interference from the participating project team in the questioning. The research was voluntary. Confidentiality was guaranteed, which ensured the privacy of the subjects and confidentiality of the data of the individuals included in the study. Frequencies were calculated for categorical variables.

${ }^{1}$ BRAZIL. Decree No. 5626 of 22 December 2005. It regulates Law No. 10.436, of April 24, 2002, which provides for the Brazilian Sign Language-Libras and art. 18 of Law No. 10.098, of December 19, 2000. Official Journal of the Union. 2005 Dec 23; Section 1-Page 28. 
Table 1. Questionnaire applied via platform SurveyMonkey.

\begin{tabular}{|c|c|}
\hline & ( ) Female \\
\hline \multirow[t]{2}{*}{ Gender } & ( ) Male \\
\hline & ( ) Do not wish to inform \\
\hline \multicolumn{2}{|l|}{ Age } \\
\hline \multirow{4}{*}{ Type of Impairment } & ( ) Hearing \\
\hline & ( ) Hearing-visual \\
\hline & ( ) Hearing-motor \\
\hline & ( ) Other \\
\hline \multirow{6}{*}{ Municipality } & ( ) Niterói \\
\hline & ( ) São Gonçalo \\
\hline & ( ) Rio Bonito \\
\hline & ( ) Itaboraí \\
\hline & ( ) Silva Jardim \\
\hline & ( ) Tanguá \\
\hline \multirow{3}{*}{$\begin{array}{l}\text { How do you define your knowledge } \\
\text { regarding the COVID-19 disease? }\end{array}$} & ( ) Don't know what it is \\
\hline & ( ) Very little knowledge \\
\hline & ( ) A lot of knowledge \\
\hline \multirow{5}{*}{$\begin{array}{l}\text { If affirmative, what was your source of } \\
\text { information regarding the COVID-19 } \\
\text { disease? }\end{array}$} & ( ) Social Media \\
\hline & ( ) Magazine/newspaper \\
\hline & ( ) Videos \\
\hline & ( ) Other \\
\hline & ( ) Does not apply \\
\hline \multirow{4}{*}{$\begin{array}{l}\text { How do you evaluate how much social } \\
\text { distancing has impacted your life? }\end{array}$} & ( ) Didn't submit to social distancing \\
\hline & ( ) It has not impacted my life \\
\hline & ( ) It has impacted a little \\
\hline & ( ) It has impacted a lot \\
\hline \multirow{8}{*}{$\begin{array}{l}\text { If affirmative, in which way did it impact } \\
\text { the most (mark the most significant } \\
\text { alternative) }\end{array}$} & ( ) Job Loss \\
\hline & ( ) Difficulty communicating through masks \\
\hline & ( ) Difficulty in health care \\
\hline & $\begin{array}{l}\text { ( ) Difficulty keeping up with physical exercises and/or } \\
\text { physical therapy }\end{array}$ \\
\hline & ( ) Lack of information about the disease \\
\hline & ( ) Impact on mental health \\
\hline & ( ) Other \\
\hline & ( ) Does not apply \\
\hline \multirow{3}{*}{ Did you test positive for COVID-19? } & ( ) Yes \\
\hline & ( ) No \\
\hline & ( ) I don't know \\
\hline \multirow{2}{*}{$\begin{array}{l}\text { Did you have contact/take care of any } \\
\text { relative or friend with COVID-19? }\end{array}$} & ( ) Yes \\
\hline & ( ) No \\
\hline
\end{tabular}




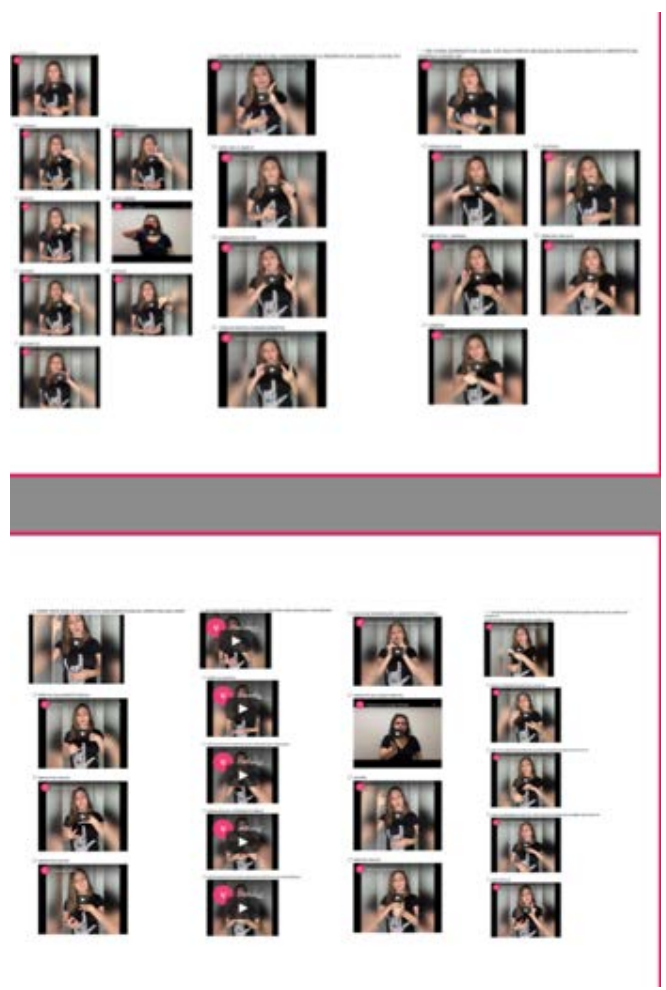

Figure 1. Questionnaire questions in Libras via platform SurveyMonkey.

The research is included in the project "Emergency Deployment of Development and Infrastructure to Support Laboratory Diagnosis of Coronavirus-19 by LAMAP/UFF (Multi-User Laboratory to Support Research in Nephrology and Medical Sciences from Federal Fluminense University) and Clinical-Laboratory Correlations, Differential Diagnoses, Evolution, and Outcomes", approved by the National Committee of Research Ethics, under number 3.987.966.

\section{Results}

From the total of 16 questionnaires answered, 16 responses were complete. Approximately $75 \%$ of the participants were female, $18.7 \%$ male, and $6.2 \%$ preferred not to indicate. The median age was 32.6 years. Regarding the severity of disability, $81.8 \%$ indicated they had only hearing impairment.

Most of the participants resided in Niterói (40\%) and Itaboraí (40\%) while the remaining $20 \%$ reside in Rio Bonito and São Gonçalo. No questionnaires were obtained from Maricá, Silva Jardim, or Tanguá, despite the researchers attempts to contact institutions supporting deaf and hearing impaired individuals living in those areas.

Regarding knowledge about COVID-19: $55.5 \%$ of respondents claim to have a lot of knowledge regarding COVID-19; $22.2 \%$ considered themselves to have little knowledge regarding the subject; $22.2 \%$ did not know what COVID-19 was. When questioned about how their knowledge was obtained: $44.4 \%$ pointed to social media; $22.2 \%$ indicated videos (without a specified platform); $22.2 \%$ se- 
lected other media; $11.1 \%$ read newspapers or magazines.

About $60 \%$ of participants said social distancing greatly impacted their lives, while the remaining $40 \%$ felt social distancing had little impact. Individuals who indicated their routines were greatly impacted by social distancing were asked in what way. $33 \%$ noted the difficulty of communication through masks, while $22 \%$ responded with loss of employment. Additional responses included difficulty in obtaining medical care as well as the impact social distancing had on mental health. The data is shown in Figure 2 below.

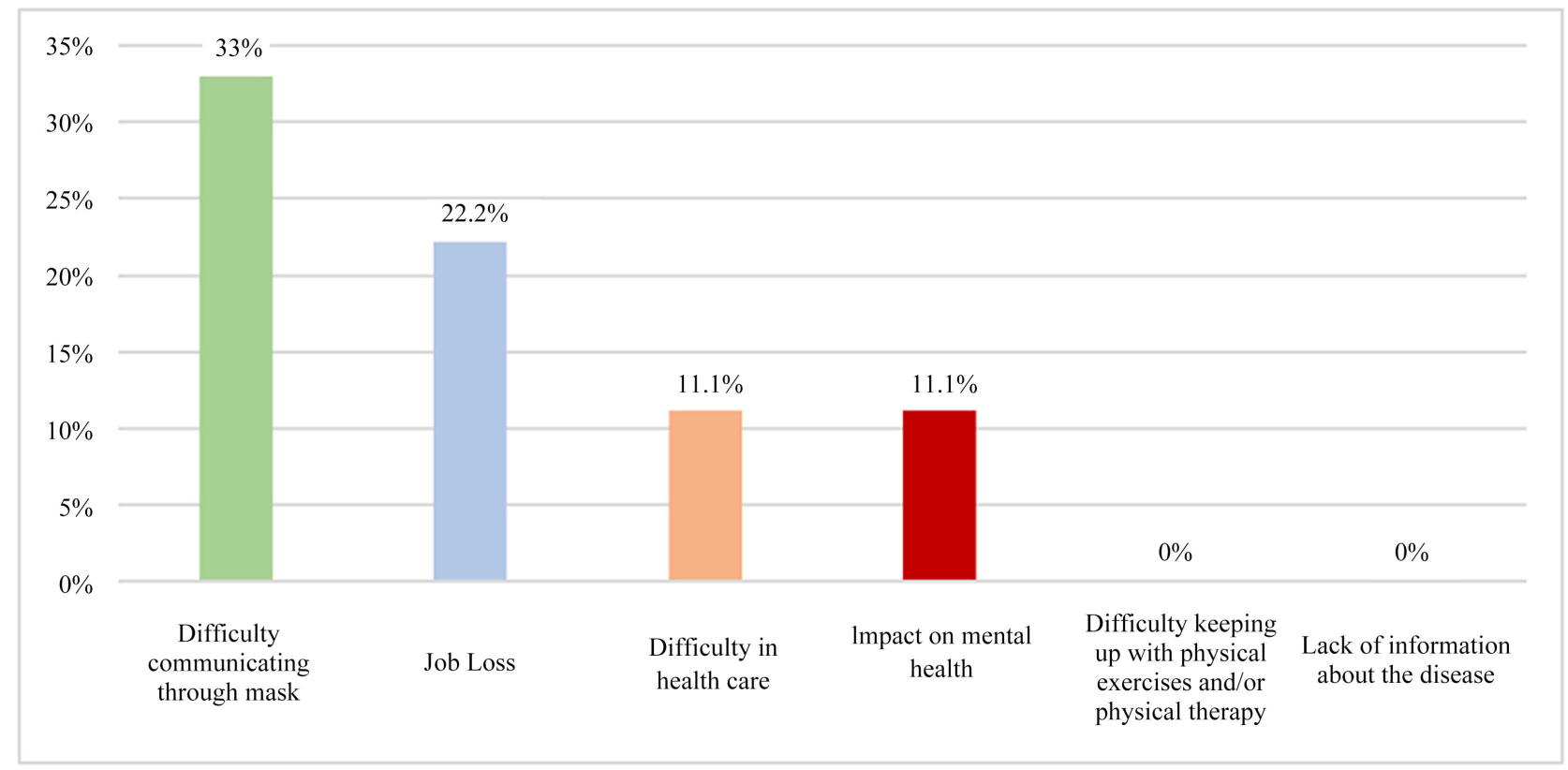

Figure 2. Aspects impacted by the SARS-CoV-2 pandemic on hearing impaired individuals.

Finally, participants were asked if they had been diagnosed with COVID-19, and if they had contact with, or needed to care for, someone diagnosed with COVID-19. 66.6\% reported they did not have contact with anyone who tested positive and had not tested positive themselves, while $33.3 \%$ did not know whether or not they tested positive for COVID-19. 11.1\% responded they had cared for a relative or friend with the disease. It is worth noting none of the participants reported having been diagnosed with COVID-19.

\section{Discussion}

The present research demonstrates the great impact the SARS-CoV-2 pandemic has on the daily lives of the deaf and hearing impaired, with $33 \%$ of the sample group pointing to the use of face masks as being the greatest obstacle. Specifically, this is due to the fact that deaf and hearing impaired persons use the facial expressions of others, as well as lip-reading, for communication with those individuals not fluent in Libras. Unfortunately, facial masks prevent the use of these mechanisms, which can hinder simple activities and even the search for needed medical care [4]. 
It was observed that $22.2 \%$ of the analysed sample group pointed to job loss as a major impact during the pandemic. According to Law No. 8.112 of December $11,1990,20 \%$ of vacancies in the public tender are directed to people with disabilities [5]. In addition, Law No. 8.213 of July 24, 1991 states companies with a minimum of 100 employees must fill $2 \%-5 \%$ of their positions with people with disabilities [6]. However, many companies argue hearing impaired individuals do not have the necessary skills and therefore only hire these individuals in order to fill vacancies as required by law. Thus, it is found deaf and hearing impaired persons suffer discrimination in the work environment since their skills, education, and qualifications are not well documented as they are often only labelled as "disabled" [7].

This situation worsens during a period of social distancing, as the pandemic has thoroughly changed the economic dynamics of the country, and the world. The population most affected by partial or total blocking measures used in several countries to curb the advancement of SARS-CoV-2 consisted of those with greater vulnerability, such as informal workers. The International Labour Organization (ILO) reiterates this fact by pointing out the following groups as those with the highest rate of lay-offs during this period: contractors, clerks, waiters, kitchen workers, housekeepers, baggage handlers, and janitors. This reality shows the increasing difficulties that every individual faces daily, including the hearing impaired, who already face several obstacles in their professional lives [8].

From the analysis of the data, it was observed that $80 \%$ of the participants in the survey resided in Niterói and Itaboraí. It was in these municipalities of Metropolitan Region II of Rio de Janeiro, in which the researchers found it easier to contact institutions supporting deaf and hearing impaired people. In the municipalities of Tanguá, Silva Jardim and Maricá, no answers were obtained due to difficulty or inability to make contact with institutions which provide assistance to people who are deaf or hearing impaired and living in those areas.

Regarding knowledge about COVID-19, it is noted that half of the participants have a lot of knowledge about the disease, while the other half had either little to no knowledge about the disease. This finding demonstrates the heterogeneity of this population, which highlights an important vulnerability and knowledge gap regarding primary information such as hand: hygiene measures; social distancing; warning signs and symptoms; and the pandemic situation at a global, national, and municipal level.

In addition, it was found that the hearing impaired mainly obtains information through social networks (44.4\%), which may imply a failure in inclusion via other means of communication. Furthermore, there is currently a higher incidence of fake news on those platforms which contradict reliable sources of information.

In a 2013 survey regarding television information conducted by Baptistella Siqueira e Silva in Curitiba on 38 deaf or hearing impaired people, it was ob- 
served that the vast majority classifies the available system, Closed Caption (hidden caption), as bad or terrible, mainly because of the lack of understanding of the caption presented and the speed in which it is transmitted. Additionally, only three (3) participants reported access to a news program utilizing an interpreter, which demonstrates a great failure in the transmission of up-to-date and pertinent information to this population [9]. In the context of the pandemic, this is exacerbated, as it is abundantly clear that accurate and timely information is crucial for individual and collective protection [10].

When it comes to mental health, it is known the deaf and hearing impaired community has a higher rate of mental disorders than the rest of the population because they tend to face more challenges and specific stressors throughout life. Social interaction, communication, and access to resources in general are important for psychological well-being. Because the pandemic has an impact on these issues, it represents a potential risk for the development and aggravation of diseases such as anxiety, depression, and post-traumatic stress disorder, as well as making more evident the limitations in access to treatment and technological resources which allow effective communication since the ones most used during this period, such as audio or video communications, cannot meet the needs [11].

Thus, the data presented shows the impact of the pandemic for deaf and hearing impaired patients and signals a lack of solid and consolidated approaches. The present study has limitations due to the small sample size. The difficulty of contacting support institutions for people with hearing impairment in the municipalities assigned to the Metropolitan Region II of Rio de Janeiro accounts for the small number of responses to this questionnaire. However, even facing such limitations, it was possible to observe a relevant impact on the life of the participants during the period of social distancing. The pandemic period has widened obstacles faced by the population of deaf and hearing impaired, and exposed new difficulties.

Thus, larger studies are needed in order to analyse more expressive samples and to understand the needs of the hearing impaired community. In addition, it is also important educational public health and care measures be designed to also support the community of people with hearing impairment in order to include them during planning, and guarantee their rights to access to health, employability, access to information, etc., which are provided for in the Constitution.

\section{Conflicts of Interest}

The authors declare no conflicts of interest regarding the publication of this paper.

\section{References}

[1] IBGE. Census 2010. Atlas Demographic Census. 2013. http://censo2010.ibge.gov.br

[2] Garcia, L.P. (2020) Use of Facemasks to Limit COVID-19 Transmission. Epidemi- 
ologia e Serviços de Saúde, 29, e2020023.

[3] Park, J. (2020) Unraveling the Invisible but Harmful Impact of COVID-19 on Deaf Older Adults and Older Adults with Hearing Loss. Journal of Gerontological Social Work, 63, 598-601. https://doi.org/10.1080/01634372.2020.1799282

[4] Chodosh, J., Weinstein, B.E. and Blustein, J. (2020) Face Masks Can Be Devastating for People with Hearing Loss. BMJ, 370, m2683. https://doi.org/10.1136/bmj.m2683

[5] BRAZIL. Law No. 8,112 of December 11, 1990. Brasília: Presidency of the Republic, Civil House, Deputy Head for Legal Affairs.

[6] BRAZIL. Ministry of Employment and Labour. Law 8.213 of July 24, 1991. Legislation on the Labour of Persons with Disabilities: Collection. TEM SIT/DSST, Brasília, 1999.

[7] Da Silva, V.S. and Garcia Bordas, M.A. (2020) Surdez, educação e trabalho. Revista Educação Especial, 33, 16 p. https://doi.org/10.5902/1984686X35960

[8] Costa, S.S. (2020) Pandemia e desemprego no Brasil. Revista de Administração Pública, 54, 969-978. https://doi.org/10.1590/0034-761220200170

[9] Baptistella Siqueira, A.C. and Silva, C.P. (2013) Dar voz a quem não é ouvido: Barreiras enfrentadas pelo surdo no acesso à informação televisiva. Caderno da Escola de Comunicação: IX Ciclo de Debates sobre Jornalismo [Internet].

https://portaldeperiodicos.unibrasil.com.br/index.php/cadernoscomunicacao/article /view/2018

[10] Ribeiro, B.S., Cabello, J. and Lins, H.A.M. (2020) Direito à participação política da comunidade surda brasileira: informação e comunicação na garantia de cidadania. Revista Humanidades e Inovação, 7, 320-335.

[11] Recio-Barbero, M., Sáenz-Herrero, M. and Segarra, R. (2020) Surdez e saúde mental: Desafios clínicos durante a pandemia COVID-19. Trauma Psicológico: Teoria, Pesquisa, Prática e Política, 12, S212-S213. https://doi.org/10.1037/tra0000729 